\title{
“Daddy, I Have Had to Kill You": Sylvia Plath's Father Poems
}

\author{
Que Jun \\ School of Foreign Languages, Beihang University, Beijing 100191, China \\ quejun@yeah.net
}

\begin{abstract}
Sylvia Plath experiences her father's death as a symbolic loss against which she struggles by coveting his love and masculine, creative power in a poetic and primitive merger with him. In a large body of her father-poetry, Plath also makes the father evoke what is for her the equivalent of death. In addition, the dangerous and even deadly father-daughter relationship is often mingled with a "romantic" narrative that entails mutual attraction and sexual tension. Eventually, Daddy and daughter were psychologically and emotionally too intertwined to be separated, even in her death.
\end{abstract}

Keywords: Sylvia Plath, father poem, death, suicide

Sylvia Plath (1932-1963), the most idiosyncratic and gifted female poet in the twentieth century, died by suicide at the age of thirty, but the gruesome fact of death, and death as a poetic subject matter, had truly mesmerized her from the time she was eight, when her father passed away in a way inexplicable to a child. Her father Otto Plath was a biology professor specializing in the study of bees, he had diabetes and could have been successfully treated, yet the stubborn man claimed that the disease he had was cancer and refused any medical treatment. By the time he was hospitalized, one leg had become gangrenous, and he died of sepsis. The death of her father was a turning point in Plath's life, as she spoke of a tangible disjunction between the time before his death and the time after: "And this is how it stiffens, my vision of that seaside childhood. My father died, we moved inland. Whereon those nine first years of my life sealed themselves off like a ship in a bottle- beautiful inaccessible obsolete, a fine, white flying myth” (Journals of Sylvia Plath 26). The dyadic departures from the father when he left her in death and from the seaside landscape ensuing his death separated her from her revered origin and sabotaged her sense of unity. Plath's vision stiffened like the cold corpse of her father. He became an "obscure" lost object from which Plath could not detach her emotional cathexis.

Plath was obsessed with her dead father, an obsession that, in her work, produced a "tangle of imagery - illogical, surreal, untrue as to the fact but inseparable from Sylvia's psychic reality" (249). Jon Rosenblatt laconically asserts that Plath's loss of father was inextricably linked to her becoming conscious of death, which ruined any sense of "original wholeness" (138). The death of the father was "the cold dead center/ where split lives congeal and stiffen to history" in her poem “A Birthday Present” (Collected Poems 207). From this “cold dead center” emerged a deep-layered identification with the father, as the Electral daughter, deprived of will and power, ruthlessly sought reunion with her ghost-father in death, which would paradoxically empower her and make her "whole" again. A. Alvarez sees that Plath was deeply involved in "the fantasy of joining or regaining her beloved dead hater, it was a passionate act, instinct as much with love as with hatred and despair" (17). Appallingly, the father's death is psychologically conceived by Plath as her first suicide, a ritual of self-destruction repetitively performed at ten year intervals in "Lady Lazarus": "I am only thirty./ And like the cat I have nine times to die./ This is number three/ What a trash/ To annihilate each decade"(Collected Poems 245). Trying to die every ten years is to identify with a father who died after the first nine years of her life. Such an obsession with death, stemmed from the sheer excessiveness of "love" and "hatred" for the dead father, is generally believed to be at the very crux of Plath's thematics. Plath continuously envisaged "death" as a kind of spirit that 
permeates the world and manifests in a wide range of objects and persons, while "life" means a "struggle for existence as the personality lives through repeated encounters with death" (Rosenblatt 22). Almost all her poems are marked by a metaphorical transformation of the external environment into the dark, macabre realm of death: The morgue-like Munich street in which "these mannequins lean tonight" ("The Munich Mannequins"); the "far fields" that "melt her heart" and "threaten" to toss her into "starless and fatherless" darkness ("Sheep in Fog"); the mausoleum-shaped honeycomb that imprisons the queen bee ("Sting"); her house with "the wall of old corpses" exuding the sense of history and death ("Letter in November"); the hospital room that wraps the female patient's body like a white sea of death (“Tulips”). Plath's speakers are placed in such a sinister, hostile, uncanny space where they face around physical annihilation.

She primarily identifies her lost and unattainable father as being enclosed in the sea, the symbol of a mysterious and unpredictable environment which she frequently imagines to be the origin of transformation from death to rebirth. The father rises with the flux of the sea, he is at once fluid and static, embracing and malignant, and the daughter "must spend years fishing, hauling up the pearl-eyed, horny, scaled and sea-bearded monster sunk long, long in the Sargasso of my imagination" (Journals of Sylvia Plath 13). With courageous and precarious brilliance, the daughter, as if in a pilgrimage, tries to confront the ghost father (also the "sea monster") and "look him in the eye" (Collected Poems 15). In "Man in Black", a poem called by Plath as a "love piece" for her father, the speaker encounters her ghostly father as he strides towards the sea with his "dead black coat", "black shoes", and "black hair" (120). He is the "fixed vortex" who holds "all of it, together" as he draws the craven daughter towards him, claiming her as his sacrifice: "fixed vortex on the far/ Tip, riveting stones, air,/ All of it, together" (120). In "All the Dead Dears", the father exists beneath the watery surface, where the generations of mothers in the mirror hauls the speaker in after him: "From the mercury-back glass/ Mother, grandmother, greatgrandmother/ Reach hag hands to haul me in,/ And an image looms under the fishpond surface/ Where the daft father went down" (70-71). In "Full Fathom Five", the Neptune-like father may be divine in his timelessness and enormity, but he also poses a threat to the daughter, who regards him with "ceaselessly loving eyes" (Rosenblatt 70), but "cannot look much" at him because she is frightened by the engulfing deep waters surrounding him: "The old myth of origins/ Unimaginable. You float near/ As keeled ice-mountains/ Of the north, to be steered clear/ Of, not fathomed. All obscurity/ Starts with a danger:/Your dangers are many" (Collected Poems 92). The daughter can only "half-believe” the "rumors" of her father's demise because he rises and falls with the tide, surfacing unpredictably"your reappearance/ Proves rumors shallow" (93). In short, the extraordinary images of the father are variously dead, archaic, risen, bestial, god-like, whose force engenders the daughter's creativity even as it annuls it.

For Plath, the father was at once a persecutory memory and an object of desire. In prevalent notions of psychoanalysis, just as a boy with an Oedipus complex craves for a sexual relationship with his mother, the daughter with an Electra complex is tormented by incestuous desire for her father. In Plath's rewriting of the Electra myth, she regresses into the father's realm and gives free reign to an unconscious desire that demands the "sticky white filth" of sexual arousal and intercourse of incest (Journals of Sylvia Plath 432). As in a Gothic romance, the father is Byronic and both "villain \& lover" (419), both oppressive and endearing, while the daughter is naive and needy, brimming with unquenchable passion and horror for her father. Thus, we see the two contradictory facets in Plath's Electral dilemma: Her necessity of garnering her father's body and love, and her necessity of denying her status as a victim of his sexual power. Eventually, Plath's preoccupation with this ambiguous father-imago led to an abandonment of her personal ambitions and desires, as she became increasingly subservient and quiet, while the dead father loomed ever larger as her "demon lover" (Collected Poems 325), constantly demanding loyalty and devotion from his daughter. In her juvenile poem “On Looking into the Eyes of a Demon Lover” , Plath's speaker, identifying herself as a wicked "witch" in full devotion to her father, seems to be 
impervious to the ravaging power of this demon-lover who burns and "char[s]" those "beauties": "I sought my image/ in the scorching glass,/ for what fire could damage/ a witch's face? (325). However, in "Conversation Among the Ruins", this "witch" can no longer be spared from the violation of her demon-lover, as he strides through the speaker's "elegant house" that encloses the zone of her inner psyche, causing a "havoc" upon her (21).

Many of Plath's late poems, especially her bee poems, emphasize the tremendous cumulative damage her father's seductive and destructive power inflicts upon her and her incessant attempt at a release from the state of psychic distress. Plath herself raised bees in her Devon home, her zealotry for the bees came from her father, who established himself as a bumblebee expert, thus "her bee-keeping becomes a way of symbolically allying herself to him, and reclaiming him from death" (Alveraz 17). In a handful of Plath's bee poems, the daughter's yearning for a symbolic and sexual alliance with the father becomes even more preponderant. "The Beekeeper's Daughter", in particular, conjoins the daughter/queen bee with the overpowering father/ bee-keeper in a strange, seclusive, and sexually charged sphere. The setting in this poem is a "garden of mouthings", where "purple, scarlet-speckled, black [...] corollas dilate, peeling back their silks" and "trumpet-throats open to the beaks of birds" (Collected Poems 118). The general ambiance is rendered all the more sensual by the "rich" air emanating from the "musk", which is "almost too dense to breath in" (118). Within this garden and its "many breasted-hives", the "mastro of the bees" moves like a sacred, massive "Hierarchical" figure - an epitome of patriarchal power which the daughter absolutely obeys and reveres (118). The speaker's self-humiliation, blind devotion and utter submission are meticulously delineated: She "kneels down" in front of this overbearing figure, her heart is crunched under his foot, and she is petrified into "sister of a stone" (118). Despite being in a garden full of "mouthings" (118), the daughter cannot find her own voice. She owns a "hole-mouth" (118), which serves not as a tool for speech, but rather a sacrifice for the father ("peeling back [its] silks for him"), as the image easily triggers the thought of sexual penetration. The sexual violence from the father implicated in the poem thus renders the silencing of the daughter, for "to the extent that woman as an object of desire is reified, she is deprived of a voice" (Stoljar 105). This "beekeeper's daughter" is hampered by her femininity and vulnerability, and denied of a voice and a full life in the iron grip of her prurient father. In the last line, the unsettling father-daughter relation takes a dramatic turn, as the woeful daughter weds herself to the father and merges into his drab, timeless, and deathly space — "The queen bee marries the winter of your year” (Collected Poems 118).

Catastrophe, anxiety, self-hatred, boundary loss - these experiences define Plath's fantasized sexual contact with her father. Even more importantly, her relation to the image of her father is characterized not only by intense erotic seductiveness but equally intense murderousness. In the intensity of the father-daughter relationship, Plath's groveling love for the father was laced with hostility, violence and patricidal rage. "He was an autocrat", Plath fiercely accuses her father in one journal entry, "I adored and despised him, and I probably wished many times that he were dead. When he obliged me and died, I imagined that I had killed him" (The Journals of Sylvia Plath 293). In her later pieces, such as "Full Fathom Five", "Electra on Azalea Path", "Little Fugue", and "Daddy", Plath manifests a distinct aggression toward the father, who is depicted as having suffered from castration (a "strange injury"), gangrene or drowning ("face down in the sea"), a shattering blast ("more than a lightning-stroke"), mutilation ("one leg”), and deformity ("one gray toe/ Big as a Frisco seal"). "Daddy", in particular, is a powerful example of a poem which can be read as a revenge against the oppressive father. When Plath read this poem for BBC radio in 1962, she introduced the poem's speaker as having an Electra complex and a confusing identity: "Here is a poem spoken by a girl with an Electra complex. Her father died while she thought he was God. Her case is complicated by the fact that her father was also a Nazi and her mother very possibly part Jewish" (SCP 293). "Daddy" is an elegy of an Electral woman for her dead father, suggesting that the persona's self can be constructed only in relation to him, or rather to his substitute. 
However, as a "murderess of maleness" (Journals of Sylvia Plath 310), Plath was nonetheless tortured with a gnawing sense of guilt - she charged herself with having murdered her father and thus deserved to be punished and killed. In the last line of "Electra on Azalea Path", the mourning speaker deeply blames herself for her father's death: "It was my love that did us both to death" (Collected Poems 117). One possibility is to read this line as an unconscious imbrication of fantasized patricide and self-slaughter elicited by her “criminal” daughterly love. Robert Phillips thus summarizes that, "a pattern of guilt over imagined incest informs all of Plath's prose and poetry" (186). In a journal entry of 1958, Plath recounts a dream in which her mother scolds her for having sex and then blames her sexual promiscuity for Otto's death. After completing "Electra on Azalea Path", Plath introspected whether guilt was the root of her "dreams of deformity and death. If I really think I killed and castrated my father may all my dreams of deformed and tortured people be my guilty visions of him or fears of punishment for me?” (Journals of Sylvia Plath 301). These "guilty visions" reemerge in "Daddy" as Plath's persona summons ghastly images of her father in an effort to exorcise them and attain her freedom from the haunting memories. Eventually, the longed-for father is violently repulsed and exorcised: "Daddy, Daddy, you bastard, I'm through" (Collected Poems 224). Plath's final words, "I'm through", convey her belief that she has finished performing the ritual of exorcism and succeeded in putting the ghost of her father to rest, yet they also suggest the speaker's demise as well as her father's. Eventually, Daddy and daughter were psychologically and emotionally too intertwined to be separated, even in death.

\section{References}

[1] Alvarez, A. The Savage God: A Study of Suicide. New York: Random Press, 1972.

[2] Plath, Sylvia. Collected Poems. Ed. Ted Hughes. New York: Harper \& Row, 1981.

[3] The Journals of Sylvia Plath. Ed. Frances McCullough and Ted Hughes. New York: Dial Press, 1982.

[4] Phillips, Robert. The Confessional Poets. Carbondale and Edwarsville: Southern Illinois University Press, 1973.

[5] Rosenblatt, Jon. Sylvia Plath: The Poetry of Initiation. Chapel Hill: University of North Carolina Press, 1979.

[6] Stoljar, Margaret Mahony. "Sirens of Gaslight and Odalisques of the Oil Lamp: The Language of Desire in the 'Arcades Project'." With the Sharpened Axe of Reason. Ed. Gerhard Fischer. Washington, D.C.: Berg Press, 1996. 99-112. 